\author{
Andrzej Ambroziak \\ Piotr Białucki \\ Wiesław Derlukiewicz \\ Artur Lange \\ Paweł Dudkiewicz
}

\title{
Wpływ liczby napraw na właściwości złączy spawanych ze stali drobnoziarnistych
}

\section{Influence of a number of repairs on fine grain steel welding joints properties}

\section{Streszczenie}

Przedstawiono wyniki badań wpływu liczby procesów naprawy złączy spawanych na ich właściwości. Badaniom poddano po 5 złączy doczołowych ze stali P460NL1 oraz S355J2+N z blach o grubości $12 \mathrm{~mm}$ obejmujących stan po spawaniu oraz po 1, 2, 3 i 4 operacjach naprawy. Zastosowane procedury badawcze złączy odpowiadały warunkom stawianym przy kwalifikowaniu technologii spawania wg PN-EN ISO 15614-1. Na podstawie badań nieniszczących VT, MT i UT zakwalifikowano badane złącza do poziomu jakości $\mathrm{B}$, wg PN-EN ISO 5815, co potwierdziły również badania metalograficzne. Badania wytrzymałości na rozciąganie, próby zginania, pomiary twardości i badania udarności wykazały, że liczba procesów naprawy spawaniem złączy doczołowych z badanych stali, przy założonym sposobie naprawy, wywiera niewielki wpływ na zmianę właściwości złączy spawanych.

\section{Abstract}

The influence of quantity of joints repairs by the means of welding on properties of joints was presented. There were investigated every 5 butt weld joints made of steel P460NL1 and S355J2+N from sheet metals thickness of $12 \mathrm{~mm}$ after 1, 2, 3 and 4 operations of repair. The investigative procedures of joints corresponds to the conditions applied by qualifying technology of welding according to the PN-EN ISO 15614-1. On the basis of NDT tests VT, MT and UT welds in investigated joint were classified to the B level of quality according to PN-EN ISO 5815 , what metallographic investigations confirmed also. The performed investigations of tensile strength, bending tests, measurements of hardness and the impact tests showed, that the quantity of processes of butt weld joints repairs, makes small influence, at set up manner of repair, on change of properties of welded joint.

\section{Wstęp}

Naprawa złączy spawanych często wynika z niespełnienia wymagań dotyczących poziomu jakości spoin. Zagadnienie liczby napraw złączy spawanych występuje także podczas remontów konstrukcji spawanych, zarówno planowych, jak i w wypadku awarii.

Dr hab. inż. Andrzej Ambroziak prof. PWr, dr inż. Piotr Białucki, dr inż. Wiesław Derlukiewicz, dr inż. Artur Lange, mgr inż. Paweł Dudkiewicz - Politechnika Wrocławska.
We właściwie opracowanej technologii spawania konstrukcji spełniającej wymagania systemów jakości ważną pozycją jest sposób naprawy wadliwych odcinków spoin. Według PN-EN ISO 3834-1:2007, w przypadku działań korygujących jakość spoin wymagane są procedury naprawy przy pełnych i standardowych wymaganiach jakości.

Zdarza się, że w naprawianej spoinie ponownie wykrywane są wady spawalnicze, które wymagają usunięcia. Powstaje przy tym pytanie, ile razy można przeprowadzać operację naprawy złącza spawanego polegającą na wycięciu wadliwego odcinka spoiny i ponownym jego spawaniu i jak wpływa liczba cykli 
spawalniczych nakładających się na siebie na zmianę właściwości złączy naprawianych.

W wytycznych dotyczących spawania łukowego stali ferrytycznych, zawartych w normach PN-EN 1011-2 jest tylko informacja o tym, że wszystkie spoiny, które nie spełniają wymagań konstrukcyjnych, powinny być naprawione, natomiast wg normy PN-EN 1011-1 w usuwaniu niezgodności spawalniczych naprawa może obejmować np. przecięcie niewłaściwie dopasowanych części i ponowne spawanie. Brakuje jednak wskazówek na temat liczby dopuszczalnych takich napraw.

Zagadnienia technologiczne związane z naprawami spawaniem konstrukcji pełnomorskich, zawarte w normach norweskich dotyczących konstrukcji offshore, wskazują na ograniczenie możliwości takich napraw [1]. Według wymagań normy NORSOK STANDARD M-101 naprawa spoiny może być wykonana tylko dwukrotnie w tym samym miejscu [4]. Spawanie naprawcze powinno być wykonane zgodnie z procedurami i instrukcjami technologicznymi spawania stosowanymi do pierwotnego wykonania złącza. Wymagane jest jednak całkowite usunięcie pierwotnej spoiny i strefy wpływu ciepła. Podobnie wg wymagań normy DET NORSKE VERITAS DNV-OS-C401 [5] dotyczącej wytwarzania i badania konstrukcji offshore to samo miejsce spawania można naprawiać tylko dwa razy, natomiast dalsze ewentualne naprawy wymagają każdorazowo indywidualnego podejścia.

Z wyników badań nad spawaniem naprawczym stali termomechanicznie walcowanych wynika, że wielokrotne naprawy spoin nie wywierają istotnego wpływu na właściwości złączy spawanych z tych stali [4]. Natomiast sposób usuwania wadliwych odcinków spoin żłobieniem ma istotny wpływ na jakość spoin [5].

\section{Materiały użyte do badań}

Przedmiotem badań były doczołowe złącza spawane z blach o grubości $12 \mathrm{~mm}$ ze stali P460NL1 i S355J2+N.

Tablica I. Skład chemiczny stali P460NL1 wg PN-EN 10028-3:2010 i atestu

Table. I. Chemical composition of P460NL1 steel acc. to PN-EN 10028-3:2010 and certificate

\begin{tabular}{|c|c|c|c|c|c|c|c|c|c|c|c|c|c|c|c|c|}
\hline \multirow[b]{2}{*}{ Znak stali } & \multicolumn{16}{|c|}{ Zawartość, \% wag. } \\
\hline & C & $\mathrm{Si}$ & $\mathrm{Mn}$ & $P$ & S & Al. & $\mathrm{N}$ & $\mathrm{Cr}$ & $\mathrm{Cu}$ & Mo & $\mathrm{Nb}$ & $\mathrm{Ni}$ & $\mathrm{Ti}$ & V & $\begin{array}{l}\mathrm{Nb}+ \\
\mathrm{Ti}+\mathrm{V}\end{array}$ & CEV \\
\hline $\begin{array}{l}\text { P460NL1 } \\
\text { (norma) }\end{array}$ & $\begin{array}{l}\max . \\
0,20\end{array}$ & $\begin{array}{l}\max . \\
0,60\end{array}$ & $\begin{array}{c}1,10 \div \\
1,70\end{array}$ & $\begin{array}{l}\max . \\
0,025\end{array}$ & $\begin{array}{l}\max . \\
0,015\end{array}$ & $\begin{array}{l}\max . \\
0,020\end{array}$ & $\begin{array}{l}\max . \\
0,025\end{array}$ & $\begin{array}{l}\max . \\
0,30\end{array}$ & $\begin{array}{l}\max . \\
0,70\end{array}$ & $\begin{array}{l}\max . \\
0,10\end{array}$ & $\begin{array}{l}\max . \\
0,050\end{array}$ & $\begin{array}{l}\max . \\
0,80\end{array}$ & $\begin{array}{l}\max . \\
0,030\end{array}$ & $\begin{array}{l}\max . \\
0,20\end{array}$ & $\begin{array}{l}\max . \\
0,22\end{array}$ & $\begin{array}{l}\max . \\
0,53\end{array}$ \\
\hline $\begin{array}{c}\text { P460NL1 } \\
\text { (atest) }\end{array}$ & 0,18 & 0,25 & 1,55 & 0,015 & 0,001 & 0,027 & 0,003 & 0,03 & 0,01 & 0 & 0,037 & 0,48 & 0 & 0,084 & 0,12 & 0,494 \\
\hline
\end{tabular}

Tablica II. Właściwości mechaniczne stali P460NL1 wg PN-EN 10028-3:2010 i atestu

Table II. Mechanical properties of P460NL1 steel acc. to. PN-EN 10028-3:2010 and certificate

\begin{tabular}{|c|c|c|c|c|c|}
\hline Oznaczenie & Stan dostawy & $\mathrm{R}_{\mathrm{eH}}, \mathrm{MPa}$ & $\mathrm{R}_{\mathrm{m}}, \mathrm{MPa}$ & $\mathrm{A} ., \%$ & Praca łamania KV, J, na próbkach poprzecznych w $-40^{\circ} \mathrm{C}$ \\
\hline P460NL1 (wg normy) & normalizowany & $\min .460$ & $570 \div 720$ & $\min .17$ & $\min .40$ \\
\hline P460NL1 (wg atestu) & normalizowany & 473 & 620 & 32 & 49,7 \\
\hline
\end{tabular}

Tablica III. Skład chemiczny stali S355J2 wg PN-EN 10025-2:2007 i atestu

Table. III. Chemical composition of S355J2 steel acc. to PN-EN 10025-2:2007 and certificate

\begin{tabular}{|c|c|c|c|c|c|c|c|c|c|c|c|c|c|c|c|c|c|}
\hline \multirow{2}{*}{ Stal } & \multicolumn{17}{|c|}{ Zawartość, \% wag. } \\
\hline & C & $\mathrm{Si}$ & $\mathrm{Mn}$ & $P$ & $S$ & $\mathrm{Ni}$ & $\mathrm{Cu}$ & $\mathrm{Cr}$ & Al & $\mathrm{Nb}$ & V & $\mathrm{Nb}$ & $\mathrm{Ti}$ & $\mathrm{N}$ & $\mathrm{Ca}$ & $\mathrm{O}$ & CEV \\
\hline $\begin{array}{l}\text { S355J2+N } \\
\text { (wg normy) }\end{array}$ & $\begin{array}{l}\max . \\
0,20\end{array}$ & $\begin{array}{l}\max . \\
0,55\end{array}$ & $\begin{array}{l}\max . \\
1,60\end{array}$ & $\begin{array}{l}\max . \\
0,025\end{array}$ & $\begin{array}{l}\max . \\
0,025\end{array}$ & - & $\begin{array}{l}\max . \\
0,55\end{array}$ & - & - & - & - & - & - & - & - & - & $\begin{array}{l}\max . \\
0,45\end{array}$ \\
\hline $\begin{array}{l}\text { S355J2+N } \\
\text { (wg atestu) }\end{array}$ & 0,13 & 0,018 & 1,43 & 0,009 & 0,004 & 0,052 & 0,07 & 0,062 & 0,068 & 0,026 & 0,003 & 0,026 & 0,001 & 0,006 & 0,003 & 0,003 & 0,39 \\
\hline
\end{tabular}

Tablica IV. Właściwości mechaniczne stali S355J2+N wg PN-EN 10025-2:2007 i atestu

Table IV. Mechanical properties of S355J2 steel acc. to. PN-EN 10025-2:2007 and certificate

\begin{tabular}{|c|c|c|c|c|}
\hline Stal & $\mathrm{R}_{\mathrm{eH}}, \mathrm{MPa}$ & $\mathrm{R}_{\mathrm{m}}, \mathrm{MPa}$ & $\mathrm{A}, \%$ & Praca łamania KV, J, na próbkach poprzecznych w temp. $-20^{\circ} \mathrm{C}$ \\
\hline S355J2+N (wg normy) & $\min .355$ & 470 do 630 & $\min .22$ & $\min .27$ \\
\hline S355J2+N (wg atestu) & 438 & 560 & 24,8 & 143 \\
\hline
\end{tabular}


Stal P460NL1 należy do grupy stali spawalnych drobnoziarnistych normalizowanych objętych normą PN-EN 10028-3:2010. Jest stalą specjalną przeznaczoną na urządzenia ciśnieniowe i konstrukcje pracujące w obniżonej temperaturze. Równoważnik węgla CEV wg normy dla wyrobów cieńszych niż $60 \mathrm{~mm}$ może wynosić maks. 0,53\%, co ma zapewnić jeszcze dobrą spawalność.

Skład chemiczny i minimalne właściwości mechaniczne stali wg normy PN-EN 10028-3:2010 zawarto w tablicach I i II, ważne są także skład chemiczny oraz właściwości mechaniczne podane w certyfikacie wystawionym przez producenta stali.

Stal S355J2+N należy do grupy jakościowych stali niestopowych o podwyższonej wytrzymałości przeznaczonych głównie na konstrukcje spawane. Chociaż nie jest objęta normą dotyczącą stali drobnoziarnistych, walcowanie normalizujące zapewnia jej drobnoziarnistą strukturę i poprawia właściwości mechaniczne. Stal jest objęta normą PN-EN 10025-2:2007. Skład chemiczny i minimalne właściwości mechaniczne wg normy oraz zawartość pierwiastków stopowych i właściwości stali S355J2+N wg certyfikatu huty podano w tablicach III i IV.

Jak widać z tablicy III, w użytej do badań stali zawartość pierwiastków stopowych jest znacznie mniejsza niż dopuszczalna wartość wg normy, należy zatem oczekiwać, że spawalność stali określona na podstawie równoważnika węgla CEV wynoszącego 0,39\% będzie lepsza niż dopuszcza norma, wg której równoważnik ten może wynosić nawet $0,45 \%$.

\section{Plan eksperymentu}

Złącza próbne o wymiarach 300×350 mm, zgodnie z normą PN-EN ISO 15614-1, spawano metodą MAG z użyciem następujących materiałów dodatkowych:

- gazu ochronnego zawierającego $82 \% \mathrm{Ar}$ i $18 \% \mathrm{CO}_{2}$ (PN-EN ISO 14175:2008 - M21);

\begin{tabular}{|c|c|c|c|c|}
\hline STAL S355J2+N zlącze: $\mathrm{nr} 1$ & $\mathrm{nr} 2$ & $\mathrm{nr} 3$ & $\mathrm{nr} 4$ & nr 5 \\
\hline $\begin{array}{l}1 \text { operacja } \\
\text { spawania }\end{array}$ & & & & \\
\hline $\begin{array}{l}2 \text { operacje spaw. } \\
\text { (w tym } 1 \text { spawanie } \\
\text { naprawcze) }\end{array}$ & & & 直 & \\
\hline $\begin{array}{c}3 \text { operacje spaw. } \\
\text { (w tym } 2 \text { spawania } \\
\text { naprawcze) }\end{array}$ & & 自 & & \\
\hline $\begin{array}{c}4 \text { operacje spaw. } \\
\text { (w tym } 3 \text { spawania } \\
\text { naprawcze) }\end{array}$ & & & & \\
\hline $\begin{array}{c}5 \text { operacje spaw. } \\
\text { (w tym } 3 \text { spawania } \\
\text { naprawcze) }\end{array}$ & & & & \\
\hline
\end{tabular}

Rys. 1. Schemat wykonania próbek ze stali S355J2+N; ze złączy w kolorze szarym pobierano próbki do badań ich właściwości Fig. 1. Scheme of S355J22+N steel specimens cutting, specimens for mechanical properties tests are in gray
- spoiwa o średnicy $1,2 \mathrm{~mm}$ G2Ni2 (PN-EN ISO 14341:2008 - G50 6 M G2Ni2) firmy Boehler do spawania stali P460NL1;

- spoiwa o średnicy 1,2 mm. G3Si1 (PN-EN ISO 14341:2008 - G 464 M G3Si1) firmy WDI do spawania stali S355J2+N.

Z każdej badanej stali wykonano po 5 złączy próbnych, z których jedno było spawane bez naprawy natomiast pozostałe były spawane wielokrotnie, tzn. odpowiednio 2, 3, 4 i 5 razy.

Przygotowanie złącza do kolejnego spawania polegało na rozcięciu wzdłuż osi spoiny złącza spawanego z poprzedniej operacji i ponownym ukosowaniu krawędzi na frezarce. Cięcie wykonywano za pomocą piły taśmowej. Spawanie tak przygotowanych złączy nazwano spawaniem naprawczym. Liczby i kolejność wykonywanych operacji spawania i cięcia przedstawiono schematycznie na rysunku 1, a przykładowy wygląd blach do spawania naprawczego pokazano na rysunku 2.

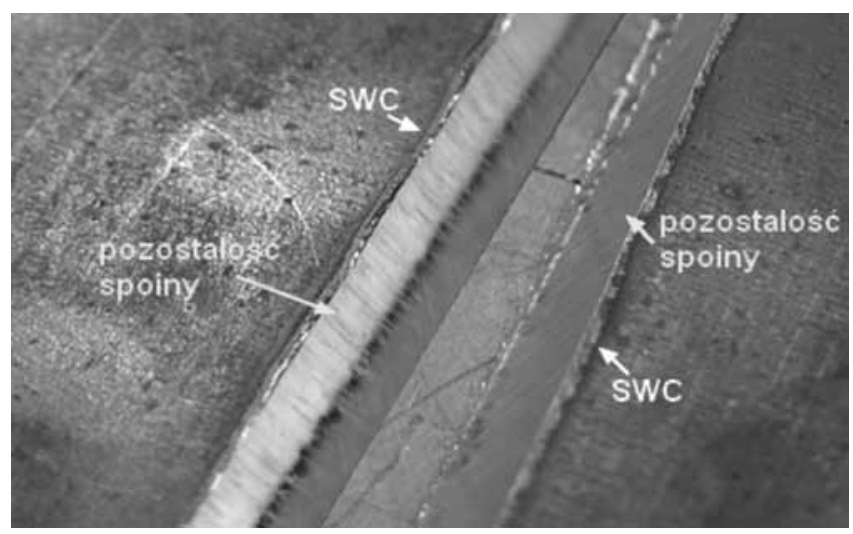

Rys. 2. Blachy ukosowane po operacji cięcia. Zaznaczono pozostałość spoiny i SWC

Fig. 2. Beveled edge of plates after cutting. Rest of weld and HAZ is marked in figure
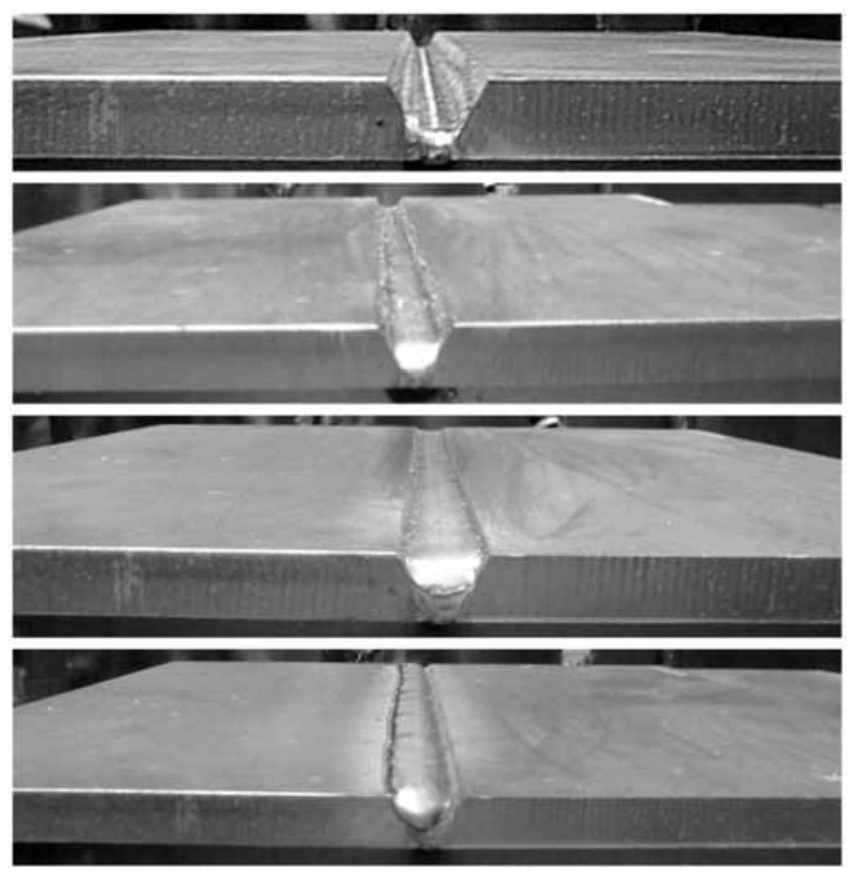

Rys. 3. Układ kolejnych czterech ściegów spoiny w złączu próbnym Fig. 3. Placement of four consecutive runs in the test joint welding 
Spawanie wszystkich złączy wykonano w pozycji podolnej bez podgrzewania wstępnego, zachowując temperaturę międzyściegową nie większą niż $180^{\circ} \mathrm{C}$. Energia liniowa spawania zmieniała się od $0,81 \mathrm{~kJ} / \mathrm{mm}$ dla ściegu pierwszego do $1,34 \mathrm{~kJ} / \mathrm{mm}$ dla ściegu ostatniego. Spoinę wykonywano w pięciu ściegach. Warunki spawania zawarto w opracowanych wcześniej instrukcjach technologicznych WPS. Przykładowy wygląd czterech kolejnych ściegów spoiny pokazano na rysunku 3.

\section{Badania nieniszczące}

Wykonane złącza próbne poddano badaniom wizualnym, magnetyczno-proszkowym i ultradźwiękowym zgodnie z odpowiednimi normami: PN-EN ISO 5817:2009, PN-EN ISO 23278:2010 oraz PN-EN ISO 11666:2011. Na podstawie przeprowadzonych badań nieniszczących stwierdzono, że spoiny spełniają wymagania poziomu jakości B wg PN-EN ISO 5718.

Po wykonaniu badań nieniszczących wycinano próbki do badań niszczących wg schematu pokazanego na rysunku 4.

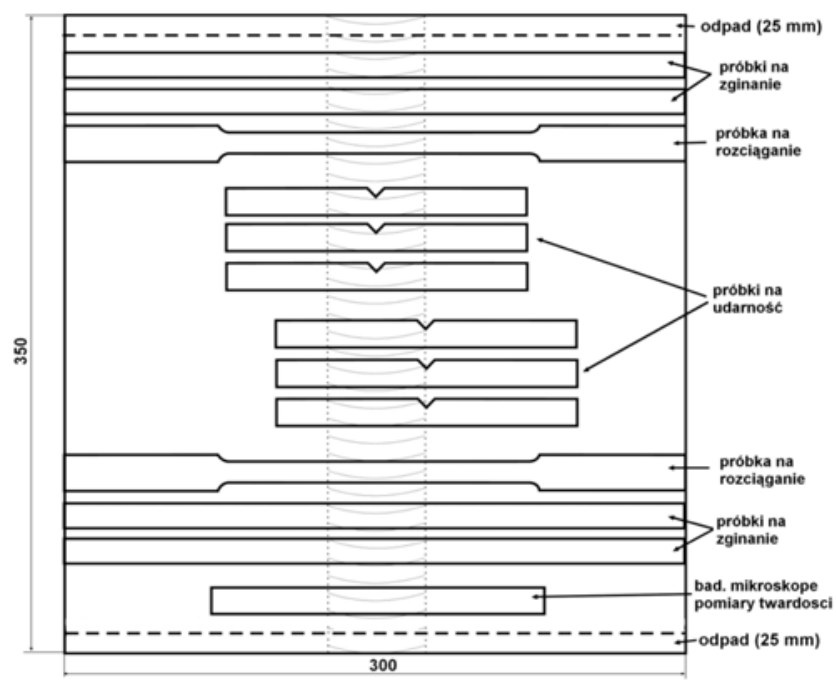

Rys. 4. Rozmieszczenie próbek do badań na złączu próbnym Fig. 4. Placement of specimens selection for tests in test joint

\section{Badania metalograficzne}

Obserwacje makroskopowe złączy z badanych próbek wykazały, że spoiny są wolne od wad makroskopowych. Makrofotografie złączy spawanych pokazano na rysunkach 5 i 6.

$\mathrm{Na}$ makrofotografiach złączy (rys. 5 i 6), można zauważyć układ kolejnych ściegów spoiny z wyraźna dendrytyczną budową ostatniego ściegu. Wyraźnie też widać drobnoziarnistą strukturę pierwszego ściegu, będącą wynikiem niskiej energii liniowej spawania, małego przekroju ściegu, dużej prędkości
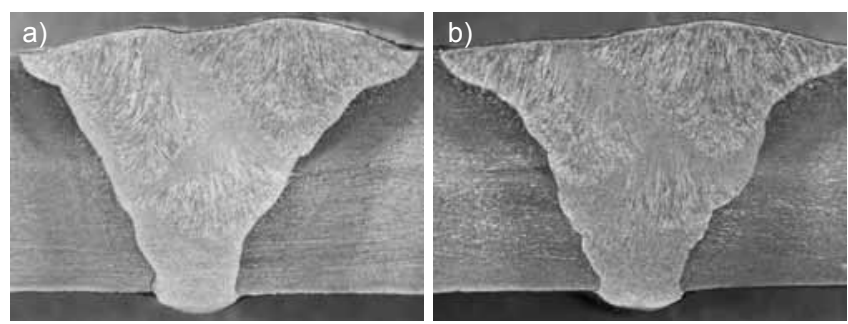

Rys. 5. Makrostruktura złączy spawanych ze stali P460NL1: a) po jednej naprawie spawaniem, b) po pięciu naprawach. Trawienie: odczynnik Adlera

Fig. 5. Macrostructure of P460NL1 steel welded joint: a) after first regeneration by welding, b) after fifth regeneration by welding, etching: Adler
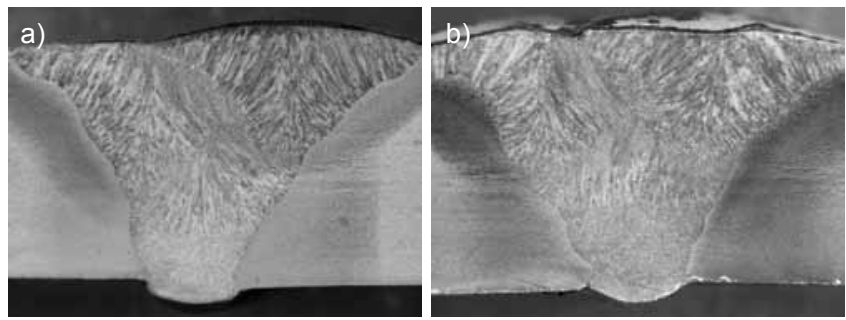

Rys. 6. Makrostruktura złączy spawanych ze stali S355J2+N: a) po jednej naprawie spawaniem, b) po pięciu naprawach. Trawienie: odczynnik Adlera

Fig. 6. Macrostructure of $\mathrm{S} 355 \mathrm{~J} 2+\mathrm{N}$ steel welded joint: a) after first regeneration by welding, b) after fifth regeneration by welding, etching: Adler

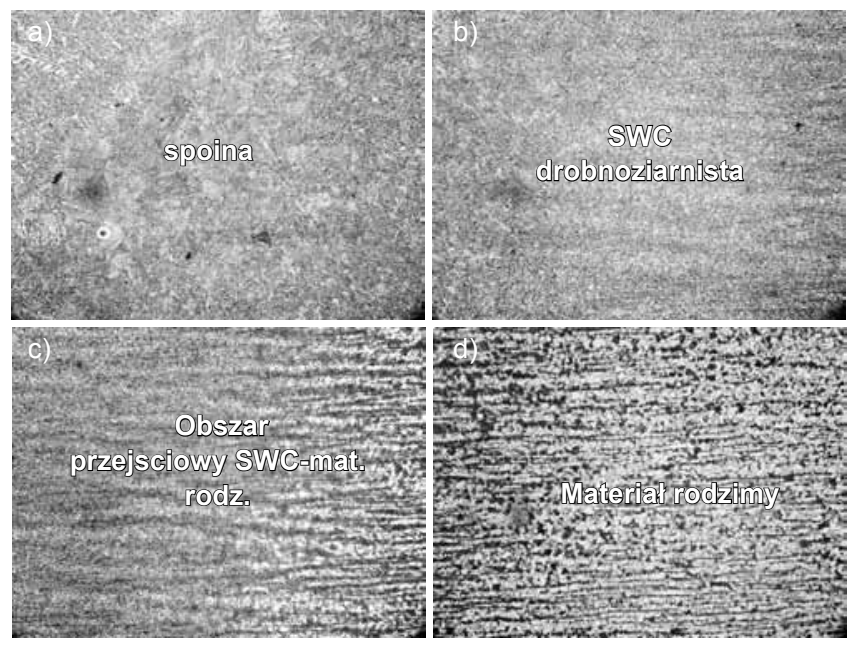

Rys. 7. Mikrostruktura złącza spawanego ze stali P460NL1. Trawienie: $3 \%$ Nital, pow. 200x

Fig. 7. Microstructure of P460NL1 steel welded joint: etching: $3 \%$ Nital, Magn. 200x

chłodzenia ściegu oraz oddziaływania cyklu cieplnego od następnych ściegów.

W mikrostrukturze złączy spawanych, można zauważyć występowanie nieciągłości materiału w postaci pęcherzyków gazowych. Na rysunku 7 przedstawiono mikrostrukturę obszaru złącza obejmującego fragment spoiny, strefę wpływu ciepła oraz strefy przejścia od SWC do materiału rodzimego.

Na rysunku 7a widać, że w bezpośrednim sąsiedztwie linii wtopienia występuje gruboziarnisty obszar strefy SWC z ferrytem Widmanstattena, który przechodzi w obszar drobnoziarnisty strefy SWC (rys. 7b), 
za którym występuje ferrytyczno-perlityczna struktura materiału rodzimego w układzie pasmowym $z$ ferrytem poligonalnym (rys. 7c, d). Gruboziarnista strefa wpływu ciepła jest wynikiem przegrzania materiału ciepłem spawania, w której temperatura była wyższa niż $1100^{\circ} \mathrm{C}$. Zwykle obszar ten ma niską plastyczność, co sprzyja łatwemu powstawaniu i rozprzestrzenianiu się w nim pęknięć.

\section{Próba zginania złączy spawanych}

Próby zginania poprzecznego z rozciąganiem od strony grani i lica spoiny czołowej wykonano zgodnie z normą PN-EN ISO 5173:2010. Na rysunku 8 przedstawiono schemat próby zginania poprzecznego z rozciąganiem lica $z$ rozstawem rolek i wymiarów trzpienia stosowanych dla złączy ze stali S355J2+N. Próbki ze stali P460NL1 zginano trzpieniem o średnicy $58 \mathrm{~mm}$ przy rozstawie rolek $95 \mathrm{~mm}$.

Próby zginania złączy próbnych wykonano na uniwersalnej maszynie wytrzymałościowej wg wymagań normy PN-EN 910. Kąt zgięcia a przy próbie rozciągania lica oraz grani dla wszystkich próbek wynosił $180^{\circ}$.
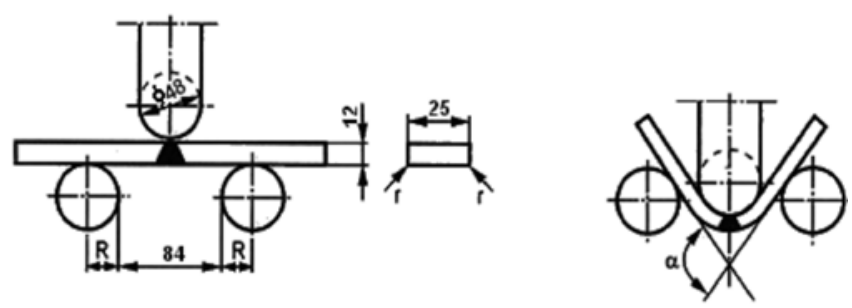

Rys. 8. Schemat próby zginania poprzecznego

Fig. 8. Scheme of lateral bend test

\section{Próba rozciągania}

Próbę rozciągania próbek poprzecznych z badanych złączy spawanych wykonano zgodnie z normą PN-EN ISO 4136. Wyniki badań przedstawiono na rysunkach 9 i 10.

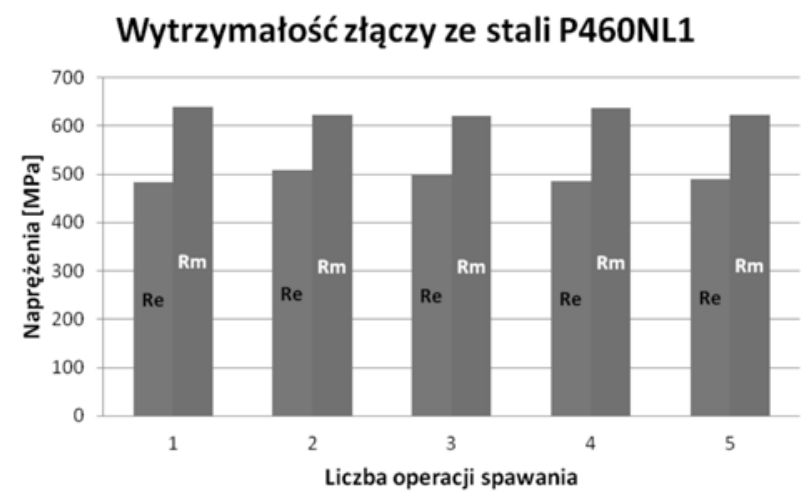

Rys. 9. Wyniki próby rozciągania próbek poprzecznych ze złączy spawanych ze stali P460NL1 po kolejnych pięciu operacjach spawania Fig. 9. Tensile test of P460NL1 steel lateral specimen of welded joint results after fiver consecutive welding operations

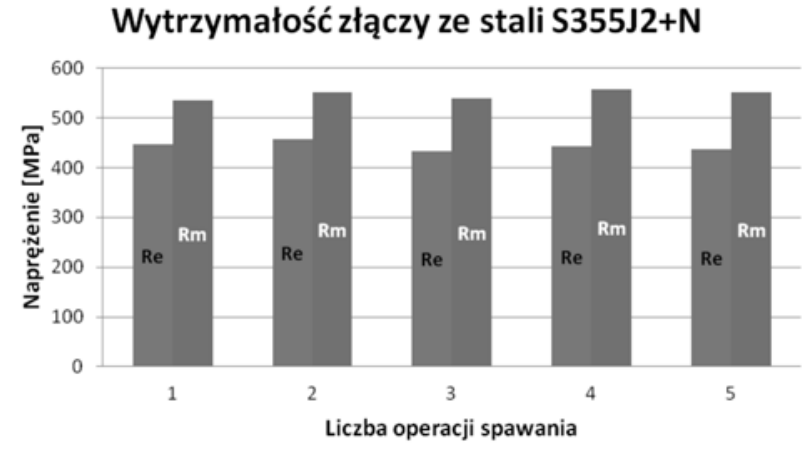

Rys. 10. Wyniki próby rozciągania próbek poprzecznych ze złączy spawanych ze stali S355J2+N po kolejnych pięciu operacjach spawania naprawczego

Fig. 10. Tensile test of S355J2+N steel lateral specimen of welded joint results after fiver consecutive welding operations

\section{Badania udarności}

Udarność próbek złączy spawanych badano zgodnie z PN-EN ISO 9016. Stosowano dwa rodzaje próbek (rys. 11). Z każdego złącza wykonano trzy próbki z karbem w spoinie i trzy próbki z karbem w SWC. W próbkach VWT karb znajdował się w osi spoiny, natomiast w próbkach VHT w SWC za linią wtopienia.

Próbki ze stali P460NL1 badano $\mathrm{w}$ temperaturze $-40^{\circ} \mathrm{C}$, natomiast próbki ze stali S355J2+N w temperaturze $-20^{\circ} \mathrm{C}$. Wyniki badań udarności przedstawiono na rysunkach 12 i 13.
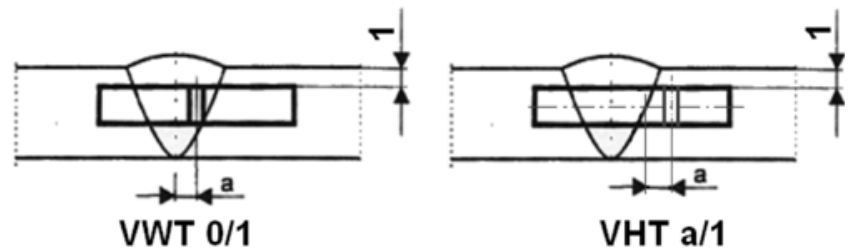

Rys. 11. Oznaczenia próbek do badań udarności złączy spawanych Fig. 11. Designation of specimen for impast test of welded joints

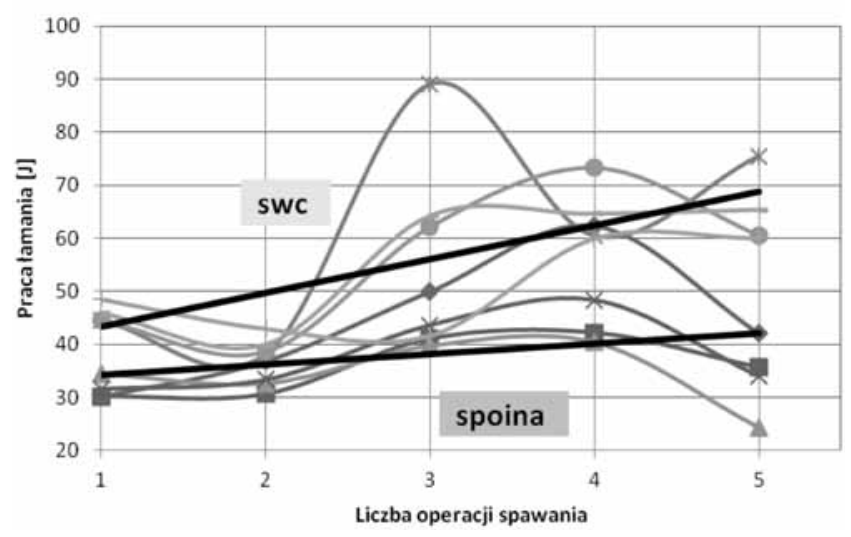

Rys. 12. Wyniki badań udarności złączy spawanych ze stali P460NL1 po kolejnych operacjach spawania naprawczego. Linie proste są liniami trendu dla wartości średnich pracy łamania

Fig. 12. Impact test of P460NL1 steel specimen of welded joint after consecutive regeneration welding operations. Straight lines are tendency lines for average values of nominal energy 


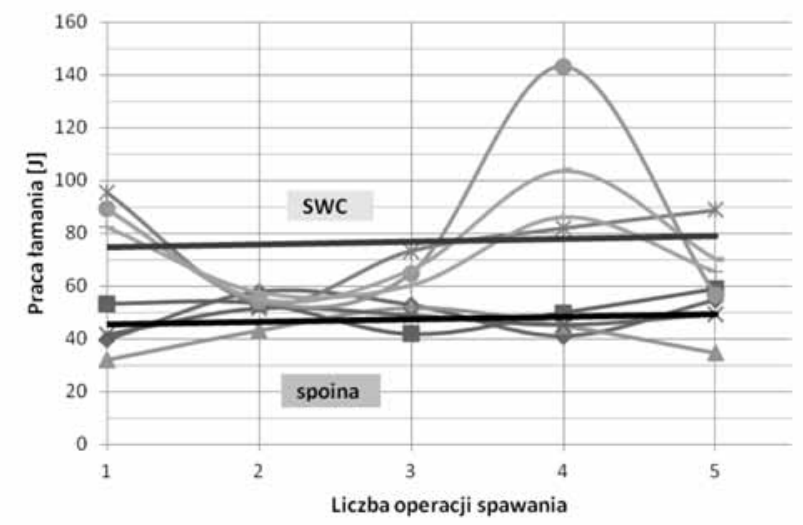

Rys. 13. Wyniki badań udarności złączy spawanych ze stali S355J2+N po kolejnych operacjach spawania naprawczego. Linie proste sa liniami trendu dla wartości średnich pracy łamania

Fig. 13. Impact test of S355J2+N steel specimen of welded joint after consecutive regeneration welding operations. Straight lines are tendency lines for average values of nominal energy

\section{Pomiary twardości}

Pomiary wykonano zgodnie z PN-EN ISO 9015-1. Twardość mierzono metodą Vickersa wzdłuż jednej linii w odległości $2 \mathrm{~mm}$ od powierzchni złącza. Wykonano po trzy punkty pomiarowe w każdym obszarze złącza, tzn. w spoinie i po obu stronach w strefach SWC i w materiale rodzimym. Wyniki pomiarów twardości przedstawiono na rysunkach 14 i 15.

\section{Wnioski}

Celem pracy było sprawdzenie, czy cztery operacje spawania naprawczego polegające na wycięciu całej lub części spoiny ze złącza ze stali P460NL1 i S355J2+N, a następnie spawaniu go ponownie, spowodują istotne zmiany właściwości mechanicznych takich jak plastyczność, wytrzymałość na rozciąganie, udarność i twardość.

W wyniku przeprowadzonych badań stwierdzono, że:

- próba zginania złączy spawanych - liczba operacji spawania nie ma wpływu na zmianę właściwości plastycznych. Wszystkie badane próbki poprzeczne ulegały zgięciu do kąta $180^{\circ}$.

- badania wytrzymałości na rozciąganie - zarówno granica plastyczności, jak i wytrzymałość na rozciąganie badanych złączy z obydwóch stali zmieniały się w bardzo niewielkim stopniu (zmiany te mieszczą się w granicach błędu pomiarów). Zatem można stwierdzić i w tym przypadku, że liczba operacji spawania naprawczego nie wywarła niekorzystnego wpływu na granicę plastyczności oraz wytrzymałość na rozciąganie.

- udarność SWC badanych złączy była większa niż udarność spoin, jednak wyniki udarności tej

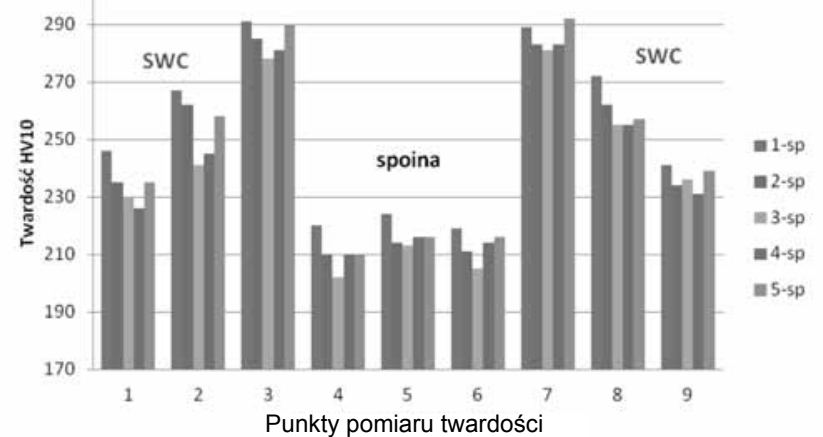

Rys. 14. Rozkład twardości w złączach spawanych ze stali P460NL1 po kolejnych pięciu operacjach spawania. Twardość materiału rodzimego $182 \mathrm{HV} 10$

Fig. 14. Hardness distribution in P460NL1 steel welded joints after five consecutive welding operations. Base metal hardness $182 \mathrm{HV} 10$

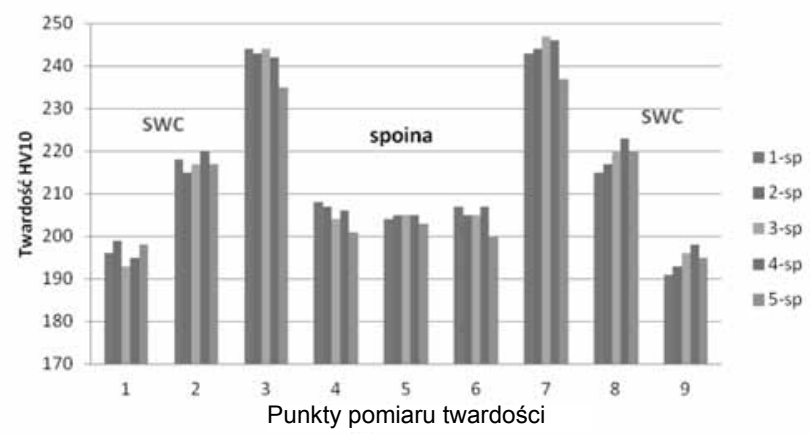

Rys. 15. Rozkład twardości w złączach spawanych ze stali S355J2+N po kolejnych pięciu operacjach spawania. Twardość materiału rodzimego $162 \mathrm{HV} 10$

Fig. 15. Hardness distribution in $\mathrm{S} 355 \mathrm{~J} 2+\mathrm{N}$ steel welded joints after five consecutive welding operations. Base metal hardness 162 HV10 strefy wykazały dużą zmienność. Twardość SWC po pierwszej naprawie w niewielkim stopniu maleje, lecz w kolejnych wyraźnie wzrasta, co szczególnie wyraźnie widać w przypadku stali P460NL1. Zmienność udarności spoiny jest wyraźnie mniejsza dla próbek ze stal $\mathrm{S} 355 \mathrm{~J} 2+\mathrm{N}$. Odnotowano jedną próbkę ze stali P460NL1 po czterech naprawach, która miała udarność $24 \mathrm{~J}$, a zatem niższą od wymaganej przez normę. Zauważoną zmienność wyników udarności próbek z SWC można wytłumaczyć nie tylko zmianami strukturalnymi po kolejnych cyklach spawania, lecz także położeniem karbu w tej strefie, które różniło się niekiedy bardziej niż oczekiwano.

- pomiary twardości - cztery operacje naprawy złączy spawaniem nie wywierają istotnych, niekorzystnych zmian. Wszystkie strefy złączy spawanych wykazują podobną twardość po każdej operacji spawania.

- analizując wartości średnie wyników poszczególnych doświadczeń - czterokrotne naprawianie złączy wg opisanej procedury nie spowodowało pogorszenia właściwości mechanicznych złączy w ocenianym zakresie. 


\section{Literatura}

[1] Pakos R., Romek E.: Konstrukcje stalowe pełnomorskie (offshore) - rodzaje, remonty. Przegląd Spawalnictwa nr 1/2009, s. 3-10.

[2] NORSOK Standard M-101. Structural steel fabrication. October 2011, ed. 5 .

[3] OFFSHORE Standard, DET NORSKE VERITAS, DNV-OS-C401. Fabrication and testing of offshore structures. October 2010

[4] Górka J.: Wpływ procesów żłobienia termicznego na właściwości stali obrobionej termomechanicznie S420 MC. Przegląd Spawalnictwa 2006, nr 9-10, s. 76-79.

[5] Górka J.: Wpływ spawania naprawczego na właściwości złączy stali obrobionych termomechanicznie. Przegląd Spawalnictwa nr 7/2005, s. 3-7.

[6] Dudkiewicz P.: Praca dyplomowa magisterska. Analiza i optymalizacja procesu naprawy niezgodności spawalniczych złączy spawanych. Promotor - P. Białucki, Wrocław, 2010.

\section{Normy}

[7] PN-EN 10028-3: 2010. Wyroby płaskie ze stali na urządzenia ciśnieniowe - Część 3: Stale spawalne drobnoziarniste normalizowane.

[8] PN-EN 10025-2:2007. Wyroby walcowane na goraco ze stali konstrukcyjnych - Część 2: Warunki techniczne dostawy stali konstrukcyjnych niestopowych.

[9] PN-EN ISO 5173:2010. Badania niszczące spoin w materiałach metalowych - Badanie na zginanie.

[10] PN-EN ISO 4136:2011. Badania niszczące złączy spawanych metali - Próba rozciągania próbek poprzecznych.

[11] PN-EN ISO 9016:2011. Badania niszczące złączy spawanych metali - Badanie udarności - Usytuowanie próbek, kierunek karbu i badanie.

[12] PN-EN ISO 9015-1:2011. Badania niszczące złączy spawanych metali - Badanie twardości - Część 1: Badanie twardości złączy spawanych łukowo.

\section{Wydarzenia}

\section{Współpraca Kemppi z zespołem Williams F1}

Kemppi podpisało umowę sponsorską z jednym $z$ wiodących zespołów Formuły 1. Zaraz po ogłoszeniu przez Kemppi i Williamsa współpracy, zespół Williamsa odniósł wspaniałe zwycięstwo w Grand Prix Hiszpanii.

Logo Kemppi jest widoczne na pasie oficjalnego, rezerwowego kierowcy Valtteriego Bottasa, oraz na tylnym spojlerze samochodu Williamsa Renault FW34. Kemppi i Williams F1 będą współpracować również w zakresie urządzeń spawalniczych. Kemppi wspiera Valtteriego Bottasa od 2008 i ta umowa jest naturalną konsekwencją zaangażowania firmy we wspieranie utalentowanych fińskich kierowców rajdowych.

W rozmowie na temat partnerstwa Dyrektor Generalny Kemppi, Anssi Rantasalo mówi: Valtteriego Botasa wspieramy od kilku lat a ta umowa jest naturalną kontynuacją współpracy. Być związanym z zespołem Williams F1, jednym z najlepszych w historii Formuły 1 to dla nas zaszczyt. Z niecierpliwością czekamy na rozszerzenie naszej współpracy w kierun-

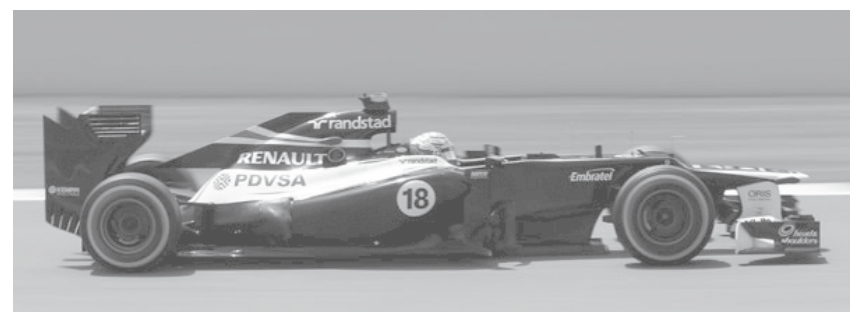

Tory wyścigowy Circuit de Catalunya, Barcelona, Hiszpania 12 maja 2012. Zaraz po ogłoszeniu przez Kemppi i Williamsa współpracy, zespół Williamsa odniósł wspaniałe zwycięstwo w Grand Prix Hiszpanii ku partnerstwa technologicznego, jako że Formuła 1 stawia wysokie wymagania technologiczne a spawanie odgrywa w niej znaczącą rolę.

Szef zespołu Williams F1, Sir Frank Williams dodaje: Jest nam niezwykle miło powitać jednego z najbardziej znanych fińskich producentów w portfolio naszych partnerów. Poprzez wspieranie kariery Valtteriego przez ostatnich kilka lat wykazali silne zaangażowanie w sporty motorowe $i$ cały zespół bardzo cieszy się na współpracę z nimi w przyszłości.

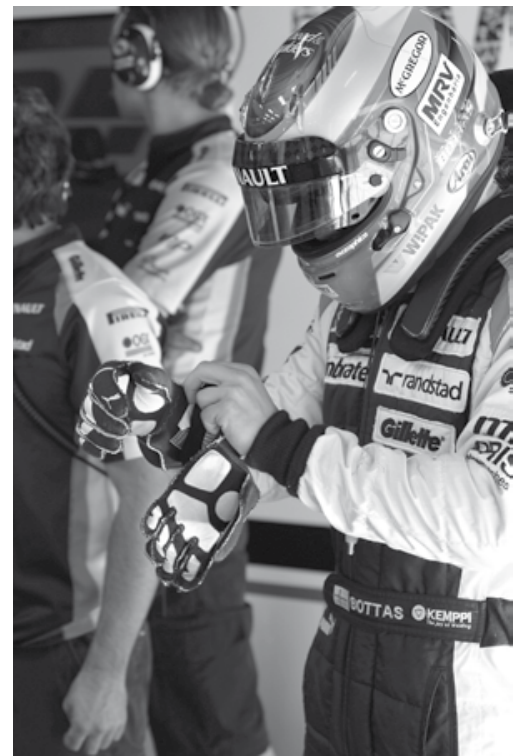

Tor wyścigowy Circuit de Catalunya, Barcelona, Hiszpania. 11 maja 2012. Valtteri Bottas, Kierowca Testowy, Zespół Williams F1. Zdjęcie: Zespół Williams F1 